\title{
Determine The Impact of Human Resources Development in Scientific Research Domain
}

\author{
Mohammad Kouchaki ${ }^{1}$, Somayyeh Ghajari ${ }^{2 *}$ \\ ${ }^{1,2}$ Department of Management, Naragh Branch, Islamic Azad University, Naragh, Iran \\ *Corresponding Author: Somayyeh Ghajari \\ sghajari@iau-naragh.ac.ir
}

\begin{abstract}
The purpose of this research is to determine the impact of human resources development in the field of scientific research. The statistical population in this study was 250 employees of faculty members of Shahid Rajaee college of Kashan. Of these, 180 cases were selected through a Grigose and Morgan table using simple random sampling. Data were collected through researcher-made questionnaires and simple random sampling. Data were analyzed by Pearson correlation and regression analysis using SPSS software. The validity of the research questions was verified by using content validity and confirmatory factor analysis method and its reliability was confirmed by Cronbach's alpha. The results and findings of the research indicate that the correlation coefficient between the intellectual factors and the scientific discourse is significant. Therefore, the first sub hypothesis that there is a significant relationship between intellectual factors and scientific discourse, the confirmation of the correlation coefficient between the attitudinal factors and scientific discourse is significant. There is a meaningful and positive relationship between attitudinal factors and scientific discourse $(r=0.758)$, correlation coefficient between job factors and scientific discourse is significant. There is a significant and positive relationship between job and academic discourse $(r=0.756)$. The finding of correlation coefficient between behavioral factors and scientific discourse is significant. There is a meaningful and positive relationship between behavioral factors and scientific discourse $(\mathrm{r}=$ 0.756). Correlation coefficient between perceptual factors and scientific discourse is significant. There is a significant and positive relationship between perceptual factors and scientific discourse $(r=0.221)$, based on the determination coefficient $(2 \mathrm{r}), 10.8 \%$ of the variance among the perceptual factors and the scientific discourse of the collaborative staff. Therefore, the fifth hypothesis is found that there is a meaningful relationship between the perceptual factors in the field of human resource development in the field of scientific education.
\end{abstract}

Keywords: human resources development, discourse, scientific environments, Shahid Rajaee Faculty 


\section{Introduction}

Proper use of human life as the most valuable and greatest wealth of any society has been considered by governments as a matter of great importance. The efficiency and effectiveness of public services and the satisfaction of the needs of the community depend on the growing role of the state and the considerable extent of how to manage and manage this wealth and vital resource. Administrative and managerial systems in developing societies like Iran are particularly important due to the limitations of skilled manpower shortages. Human resource management means understanding the importance of an organization's human resources that shapes and favors organizational excellence, customer focus, entrepreneurship, quality, and so on. In the universities of the country, it will not be possible to develop economic infrastructure, reform the pattern of consumption, change lifestyle, support domestic production, pay attention to the quality of production and other economic and political arenas of the country without the intelligent and intimate participation of students and student elites. Basically, in today's world, the main burden is the development of economic and political policies by the media and the discursive tools. Regularization of university human resources is one of the most important factors affecting the academic discourse of universities, because the diffusion of morale, motivation and willingness in human resources and faculty members and university researchers to research depends on the establishment of a system and the systematization of Human resources affairs. One of the concerns of the Human Resources Education Committees of the Shahid Rajaee Technical College of Kashan is that according to the existing laws and the requirement to provide specific training hours for staff, it is necessary to provide a suitable bedside for all employees to complete the required hours during the year. Human resource development training was also put on the agenda of the universities due to the need for facilities and expenses. Unfortunately, this method did not have the required productivity for various reasons. Therefore, the attention of the technical faculty members should be taken into consideration. This research responds to the question of how human resource development has an impact in the field of scientific research?

\section{Previous research}

Bassiri (2016) conducted a research entitled "Future Studies Required for Human Resources Planning in Future Uncertainty Conditions". He stated in his article that, in the current situation, the prediction of distant horizons is difficult and sometimes unexpected accidents, like a tsunami, shatter the foundation of plans, including strategic plans. Under these circumstances, it is unreasonable to ignore planning and expose ourselves to incidents. In the present research, the first is the difference between the strategic management and strategic planning, and then, by explaining the current conditions of the world and the uncertainty in the internal conditions and in particular the external organizations and decision centers, it is necessary to use the methods and techniques of future studies in The process of decision making and strategic planning has been emphasized and decision-making with a futuristic perspective is presented as a good solution to escaping current uncertainties. Ultimately, a sustained planning approach is briefly described as a strategic planning approach to respond to unexpected accidents.

Tahmasebi (2015) conducted a research entitled "Investigating their Role in Human Resource Management". He stated that perhaps one of the most important forums about thinking about the future could be the words of Allan Kay, the inventor of the graphical computer interface that led to the design of the Windows operating system. He says the best way to predict the future of the future. Look forward And designing a vision is one of the most important suggestions of a modern and excellent state. Today, most countries have long-term plans for 
their particulars, but some of these programs are coming to an end, and many will be defective for some time.

Alavi Matin (2015) conducted a research entitled "Identifying and Developing an Appropriate Human Resource Strategy". The methodology of this research is descriptivesurvey and is a kind of analytical and purposeful application. The standard questionnaire was distributed among respondents with a statistical population of 80 individuals including 66 managers and supervisors of the bank. To measure the components of the human resources strategy, the strategy of human resource bank was used to analyze and confirm the factor analysis and to prioritize the effective components of Friedman test strategy using SPss and Lisrel software. According to the results of Friedman test, among the five dimensions, the dimension of the supply of power, and then the relationship of employees has the least impact on the development of human resources strategy. Using the mean, standard deviation and coefficient of variation tests, the results indicate that the Mehreman Bank's human resources strategy is secondary and that the human resources supply strategy, as a traditional supply strategy, is the strategy of education and development as a general development strategy, Performance evaluation strategy, as a strategy for standardization, compensation strategy and reward, as a rewarding skill strategy, employee retention strategy, as a supportive strategy.

Safari (2015), a research conducted "Identifying Human Resources Strategy Using Theory of Strategic Reference Points Case Study: Service Contractors, Parsian Gas Refining Company". In this research, the process of identification of human resources strategy is described in Parsian Gas Refining Company's services contracting companies. The total staff of the Parsian Gas Refinery Company is 8811 , of which 473 are officially 841 contractors and 676 are contract service personnel. The results show that the appropriate strategy for service contracting companies is Parsian Gas Refining Company based on Bamburger and Molsulm's integrated approach to all three subsystems of the secondary strategy and based on the developed model, the strategy of the Secondary Transfer Strategy and "Arabic Human Resources In simple terms, the appropriate strategies for assigning contractors to the contractor are the appropriate strategies. Also, based on the average score table, according to the Friedman test, the subsystem of performance appraisal and reward is the highest score and the subsystem is the relationship with the staff with the lowest score.

Marginson et al. (2016) in a study by British corporations, They did not succeed in finding a clear link between human resources and human resource management.

A study Purcell and Alsterland (2015) on multidimensional companies showed that human resource management issues are rarely considered in the formulation of business strategies.

A study by Downie and Coates (2014) on Canadian companies reported that human resource management is somewhat more strategic. The study found that Canadian HR managers are often out of the reach of decision making.

Peck's (2014) research on the relationship between strategy, human resource policies and employment effects in 45 US companies concluded that the relationship between these three is "more complicated than previously thought."

\section{Methodology}

1. Investigating the research hypotheses 
1.1 First sub hypothesis: The intellectual factors affecting the development of human resources in the field of discourse in the scientific environment.

Table 1: Correlation coefficient between variable of intellectual factors and scientific discourse

\begin{tabular}{|c|c|c|c|}
\hline Criterion variable & \multirow{2}{*}{\multicolumn{3}{|c|}{ Scientific discourse }} \\
\hline \multirow[b]{2}{*}{ Predictive variables } & & & \\
\hline & $\begin{array}{l}\text { Correlation } \\
\text { Coefficient }\end{array}$ & $\begin{array}{c}\text { Correlation coefficient } \\
\text { squared }\end{array}$ & $\begin{array}{c}\text { Significance level } \\
\text { (P-valeu) }\end{array}$ \\
\hline Intellectual factors & $0 / 778$ & $0 / 605$ & $0 / 000$ \\
\hline
\end{tabular}

Findings of Table (1) show that the scoring coefficient between the intellectual factors and the scientific discourse is significant. There is a significant and positive effect between intellectual factors and scientific discourse $(r=0.778)$, based on the determination coefficient $\left(r^{2}\right), 60.5 \%$ of the variance between the factors of thought and the common scientific discourse. Therefore, the first hypothesis is that there is a significant effect between intellectual factors and scientific discourse, is confirmed.

Table 2: The meaningful step-by-step regression model in the first hypothesis

\begin{tabular}{|c|c|c|c|c|c|c|}
\hline Model & \multicolumn{2}{|c|}{ Predictive variable } & $\begin{array}{c}\text { Sum of } \\
\text { squares }\end{array}$ & $\begin{array}{c}\text { Average of } \\
\text { squares }\end{array}$ & F statistics & $\begin{array}{c}\text { p-value } \\
\text { (significance) }\end{array}$ \\
\hline \multirow{2}{*}{1} & \multirow{2}{*}{$\begin{array}{c}\text { Intellectual } \\
\text { factors }\end{array}$} & Regression & $114 / 563$ & $114 / 563$ & $334 / 563$ & $0 / 000$ \\
\cline { 3 - 7 } & & remainder & $84 / 638$ & $0 / 343$ & & \\
\cline { 2 - 7 } & & Total & $199 / 201$ & & & \\
\hline
\end{tabular}

According to the results obtained from Table (2) and the meaningful value of P-value obtained in two stages of zero and thought factors have been able to predict Scientific discourse. It has been concluded that the relationship between intellectual factor and scientific discourse has a significant relationship and regression model is a meaningful model and intellectual factors can predict scientific discourse.

Table 3: Summary of the regression model step by step first hypothesis

\begin{tabular}{|c|c|c|c|c|c|c|c|}
\hline \multirow[t]{2}{*}{ Model } & \multirow{2}{*}{$\begin{array}{l}\text { Predictive } \\
\text { variable }\end{array}$} & \multirow{2}{*}{$\begin{array}{c}\text { Coefficient } \\
\text { Scale }\end{array}$} & \multirow{2}{*}{$\begin{array}{l}\text { Coefficient } \\
\text { scrolling } \\
\text { square }\end{array}$} & \multicolumn{4}{|c|}{ Statistics } \\
\hline & & & & $\begin{array}{c}\text { Changes } \\
\text { F }\end{array}$ & $\begin{array}{l}\text { Degrees } \\
\text { of } \\
\text { freedom } \\
1\end{array}$ & $\begin{array}{l}\text { Degrees } \\
\text { of } \\
\text { freedom } \\
2\end{array}$ & $\begin{array}{c}\text { Durbin } \\
\text { Watson } \\
\text { test }\end{array}$ \\
\hline 1 & $\begin{array}{l}\text { Intellectual } \\
\text { factors }\end{array}$ & $0 / 758$ & $0 / 575$ & $334 / 330$ & 1 & 247 & \\
\hline
\end{tabular}

The results from Table (3) show that Intellectual factors in the second step have 60/5\% ability to predict scientific discourse. 
Table 4: Coefficients of the regression model of the first sub-hypothesis

\begin{tabular}{|c|c|c|c|c|c|c|c|c|}
\hline \multirow{2}{*}{\multicolumn{2}{|c|}{$\begin{array}{c}\text { Predictive } \\
\text { variable model }\end{array}$}} & \multicolumn{2}{|c|}{$\begin{array}{l}\text { Non-standard } \\
\text { coefficients }\end{array}$} & \multirow{3}{*}{$\begin{array}{l}\text { Standard } \\
\text { beta } \\
\text { coefficients }\end{array}$} & \multirow{2}{*}{$\begin{array}{c}\text { The } \\
\text { statistics } \\
T\end{array}$} & \multirow[t]{2}{*}{$\begin{array}{c}\mathrm{p} \text {-value } \\
\text { (significance) }\end{array}$} & \multicolumn{2}{|c|}{ Collinearity statistics } \\
\hline & & Beta & The & & & & tolerance & Multicolinearity \\
\hline \multirow[t]{2}{*}{1} & $\begin{array}{c}\text { Constant } \\
\text { coefficient }\end{array}$ & $0 / 754$ & $0 / 138$ & & $5 / 451$ & $0 / 000$ & & \\
\hline & $\begin{array}{l}\text { Intellectual } \\
\text { factors }\end{array}$ & $0 / 737$ & $0 / 040$ & $0 / 758$ & $18 / 285$ & $0 / 000$ & $1 / 000$ & $1 / 000$ \\
\hline
\end{tabular}

As can be seen in Table 4, in step two, stepwise regression, the intellectual factors with a tvalue of 5/451 and a significant level of $0 / 000$ at $95 \%$ confidence level can significantly predict the dependent variable of the scientific discourse And the regression line equation with nonstandard coefficients is as follows.

$$
\text { scientific discourse }=0 / 737 \text { Intellectual factors }+0 / 754
$$

1.2 Second sub hypothesis: Second sub hypothesis: The attitude factors affecting the development of human resources in the field of discourse in the scientific environment.

Table 5: Correlation coefficient between the variable of attitudinal factors and scientific discourse

\begin{tabular}{|c|c|c|c|}
\hline Criterion variable & \multicolumn{3}{|c|}{ Scientific discourse } \\
\hline \multirow{2}{*}{ Predictive variables } & $\begin{array}{c}\text { Correlation } \\
\text { Coefficient }\end{array}$ & $\begin{array}{c}\text { Correlation coefficient } \\
\text { squared }\end{array}$ & $\begin{array}{c}\text { Significance level } \\
\text { (P-valeu) }\end{array}$ \\
\cline { 2 - 4 } & $* * 0 / 756$ & $0 / 571$ & $0 / 000$ \\
\hline Attitude Factors & & 0 & \\
\hline
\end{tabular}

Findings of Table 5 show that the Scrolling coefficient between the attitudinal factors and the scientific discourse is Meaningful. There is a significant and positive effect between attitudinal factors and scientific discourse $(r=0.758)$, Based on the coefficient of determination $\left(\mathrm{r}^{2}\right)$, $60.5 \%$ of the variance was between the attitudes and scientific discourse. Therefore, the second sub hypothesis that there is a significant effect between attitudinal factors and scientific discourse is confirmed.

Table 6: Significance of a stepwise regression model in the second sub hypothesis

\begin{tabular}{|c|c|c|c|c|c|c|}
\hline Model & \multicolumn{2}{|c|}{ Predictive variable } & $\begin{array}{c}\text { Sum of } \\
\text { squares }\end{array}$ & $\begin{array}{c}\text { Average of } \\
\text { squares }\end{array}$ & F statistics & $\begin{array}{c}\text { p-value } \\
\text { (significance) }\end{array}$ \\
\hline \multirow{2}{*}{1} & \multirow{2}{*}{$\begin{array}{l}\text { Attitude } \\
\text { Factors }\end{array}$} & Regression & $34 / 012$ & $34 / 012$ & $174 / 527$ & $0 / 000$ \\
\cline { 3 - 7 } & & remainder & $47 / 552$ & $0 / 195$ & & \\
\cline { 3 - 7 } & & Total & $81 / 564$ & & & \\
\hline
\end{tabular}

According to the results obtained from Table (6) and the meaningful value of P-value obtained in two stages of zero, and between the elements of attitudinal factors, has been able to predict scientific discourse. As a result, there is a significant relationship between attitudinal factors and scientific discourse and regression model is a meaningful model and attitudinal factors are able to predict scientific discourse. 
Table 7: Summary of the Step-by-step regression model of the second sub-hypothesis

\begin{tabular}{|c|c|c|c|c|c|c|c|}
\hline \multirow[t]{2}{*}{ Model } & \multirow{2}{*}{$\begin{array}{l}\text { Predictive } \\
\text { variable }\end{array}$} & \multirow{2}{*}{$\begin{array}{c}\text { Coefficient } \\
\text { Scale }\end{array}$} & \multirow{2}{*}{$\begin{array}{c}\text { Coefficient } \\
\text { scrolling } \\
\text { square }\end{array}$} & \multicolumn{4}{|c|}{ Statistics } \\
\hline & & & & $\begin{array}{c}\text { Changes } \\
\text { F }\end{array}$ & $\begin{array}{l}\text { Degrees } \\
\text { of } \\
\text { freedom } \\
1\end{array}$ & $\begin{array}{l}\text { Degrees } \\
\text { of } \\
\text { freedom } \\
2\end{array}$ & $\begin{array}{c}\text { Durbin } \\
\text { Watson } \\
\text { test }\end{array}$ \\
\hline 1 & $\begin{array}{l}\text { Attitude } \\
\text { factors }\end{array}$ & $0 / 646$ & $0 / 417$ & $34 / 527$ & 1 & 245 & \\
\hline
\end{tabular}

The results from Table (7) show that the attitudinal factors of dimensions in the first step are $64.6 \%$ of the ability to predict scientific discourse.

Table 8: Regression coefficients of the second sub hypothesis

\begin{tabular}{|c|c|c|c|c|c|c|c|c|}
\hline \multicolumn{2}{|c|}{$\begin{array}{c}\text { Predictive } \\
\text { variable model }\end{array}$} & \multicolumn{2}{|c|}{$\begin{array}{l}\text { Non-standard } \\
\text { coefficients }\end{array}$} & \multirow{3}{*}{$\begin{array}{l}\text { Standard } \\
\text { beta } \\
\text { coefficients }\end{array}$} & \multirow{3}{*}{$\begin{array}{c}\text { The } \\
\text { statistics } \\
\text { T } \\
\\
14 / 168\end{array}$} & \multirow{3}{*}{$\begin{array}{c}\text { p-value } \\
\text { (significance) } \\
\\
0 / 000\end{array}$} & \multicolumn{2}{|c|}{ Collinearity statistics } \\
\hline & & Beta & & & & & tolerance & Multicolinearity \\
\hline \multirow[t]{2}{*}{1} & $\begin{array}{l}\text { Constant } \\
\text { coefficient }\end{array}$ & $1 / 782$ & $0 / 126$ & & & & & \\
\hline & $\begin{array}{l}\text { Attitude } \\
\text { factors }\end{array}$ & $0 / 528$ & $0 / 040$ & $0 / 646$ & $13 / 211$ & $0 / 000$ & $1 / 000$ & $1 / 000$ \\
\hline
\end{tabular}

As can be seen in table (8), in step two, stepwise regression, attitudinal factors with a t-value of 168/14 and a significant level of 0,000 at 95\% confidence level, Mseaningfully predicted the power The dependent variable is a scientific discourse and the equation of regression line with non-standard coefficients is as follows.

$$
\text { scientific discourse }=0 / 528 \text { Attitude factors }+1 / 782
$$

1.3 Third sub-hypothesis: Occupational factors in the field of human resource development are affecting in the scientific environment.

Table 9: Correlation Coefficient between Job Variables and Scientific Discourses

\begin{tabular}{|c|c|c|c|}
\hline Criterion variable & \multirow{2}{*}{\multicolumn{3}{|c|}{ Scientific discourse }} \\
\hline \multirow[b]{2}{*}{ Predictive variables } & & & \\
\hline & $\begin{array}{l}\text { Correlation } \\
\text { Coefficient }\end{array}$ & $\begin{array}{c}\text { Correlation coefficient } \\
\text { squared }\end{array}$ & $\begin{array}{c}\text { Significance level } \\
\text { (P-valeu) }\end{array}$ \\
\hline Job Variables & $* * 0 / 758$ & $0 / 575$ & $0 / 000$ \\
\hline
\end{tabular}

Findings of Table (9) show that the survey coefficient between job factors and the scientific discourse is significant. That is, there is a significant and positive relationship between job and academic discourse $(r=0.756)$, Based on the coefficient of determination $(2 \mathrm{r}), 57.5 \%$ of the variance was found between the factors of job and scientific discourse. Therefore, there is a third hypothesis that there is a significant effect between the factors of job and scientific discourse. 
Table 10: Significance of stepwise regression model in third sub hypothesis

\begin{tabular}{|c|c|c|c|c|c|c|}
\hline Model & \multicolumn{2}{|c|}{ Predictive variable } & $\begin{array}{c}\text { Sum of } \\
\text { squares }\end{array}$ & $\begin{array}{c}\text { Average of } \\
\text { squares }\end{array}$ & F statistics & $\begin{array}{c}\text { p-value } \\
\text { (significance) }\end{array}$ \\
\hline \multirow{2}{*}{1} & \multirow{2}{*}{$\begin{array}{c}\text { Job } \\
\text { Variables }\end{array}$} & Regression & $2 / 327$ & $2 / 327$ & $7 / 164$ & $0 / 000$ \\
\cline { 3 - 7 } & remainder & $79 / 237$ & $0 / 325$ & & \\
\cline { 2 - 6 } & Total & $81 / 564$ & & & \\
\hline
\end{tabular}

According to the results obtained from Table 10 and the meaningful value of P-value obtained in two stages of zero and between the factors of job factors, it has been possible to predict scientific discourse. As a result, the relation between the factors of job with scientific discourse, There is a significant relationship between the regression model and the attitudinal factors that can predict the scientific discourse.

Table 11: Summary of Stepwise Regression Model Third Sub-hypothesis

\begin{tabular}{|c|c|c|c|c|c|c|c|}
\hline \multirow[t]{2}{*}{ Model } & \multirow{2}{*}{$\begin{array}{l}\text { Predictive } \\
\text { variable }\end{array}$} & \multirow{2}{*}{$\begin{array}{l}\text { Coefficient } \\
\text { Scale }\end{array}$} & \multirow{2}{*}{$\begin{array}{l}\text { Coefficient } \\
\text { scrolling } \\
\text { square }\end{array}$} & \multicolumn{4}{|c|}{ Statistics } \\
\hline & & & & $\begin{array}{c}\text { Changes } \\
\text { F }\end{array}$ & $\begin{array}{l}\text { Degrees } \\
\text { of } \\
\text { freedom } \\
1\end{array}$ & $\begin{array}{l}\text { Degrees } \\
\text { of } \\
\text { freedom } \\
2\end{array}$ & $\begin{array}{c}\text { Durbin } \\
\text { Watson } \\
\text { test }\end{array}$ \\
\hline 1 & $\begin{array}{c}\text { Job } \\
\text { Variables }\end{array}$ & $0 / 169$ & $0 / 029$ & $7 / 164$ & 1 & 245 & \\
\hline
\end{tabular}

The results obtained from Table (11) show that occupational factors of dimensions in the first step are $64.6 \%$ of the ability to predict scientific discourse.

Table 12: Regression model coefficients of the third sub-hypothesis

\begin{tabular}{|c|c|c|c|c|c|c|c|c|}
\hline \multicolumn{2}{|c|}{$\begin{array}{c}\text { Predictive } \\
\text { variable model }\end{array}$} & \multicolumn{2}{|c|}{$\begin{array}{l}\text { Non-standard } \\
\text { coefficients }\end{array}$} & \multirow{3}{*}{$\begin{array}{c}\text { Standard } \\
\text { beta } \\
\text { coefficients }\end{array}$} & \multirow{3}{*}{$\begin{array}{c}\text { The } \\
\text { statistics } \\
\text { T } \\
\\
14 / 088\end{array}$} & \multirow{3}{*}{$\begin{array}{c}\mathrm{p} \text {-value } \\
\text { (significance) } \\
\\
0 / 000\end{array}$} & \multicolumn{2}{|c|}{ Collinearity statistics } \\
\hline & & \multirow{2}{*}{$\begin{array}{l}\text { Beta } \\
2 / 865\end{array}$} & \multirow{2}{*}{$\begin{array}{c}\text { The } \\
\text { standard } \\
\text { error } \\
0 / 203\end{array}$} & & & & tolerance & Multicolinearity \\
\hline 1 & $\begin{array}{c}\text { Constant } \\
\text { coefficient }\end{array}$ & & & & & & & \\
\hline & $\begin{array}{c}\text { Job } \\
\text { Variables }\end{array}$ & $0 / 168$ & $0 / 063$ & $0 / 169$ & $2 / 677$ & $0 / 000$ & $1 / 000$ & $1 / 000$ \\
\hline
\end{tabular}

As can be seen in table (12), in step one, stepwise regression, job Variables with t-value of 088/14 and a significant level of $0 / 000$ at $95 \%$ confidence level can significantly predict the dependent variable of scientific discourse And the regression line equation with non-standard coefficients is as follows.

scientific discourse $=0 / 168$ Job Variables $+2 / 865$

1.4 Fourth sub-hypothesis: Behavioral factors affect the development of human resources in the scientific environment. 
Table 13: Correlation coefficient between behavioral factors variable and scientific discourse

\begin{tabular}{|c|c|c|c|}
\hline Criterion variable & \multicolumn{3}{|c|}{ Scientific discourse } \\
\hline \multirow{2}{*}{ Predictive variables } & $\begin{array}{c}\text { Correlation } \\
\text { Coefficient }\end{array}$ & $\begin{array}{c}\text { Correlation coefficient } \\
\text { squared }\end{array}$ & $\begin{array}{c}\text { Significance level } \\
\text { (P-valeu) }\end{array}$ \\
\cline { 2 - 4 } & ${ }^{* *} 0 / 556$ & $0 / 309$ & $0 / 000$ \\
\hline behavioral factors &
\end{tabular}

Findings of Table (13) show that the survey coefficient between the behavioral factors and the scientific discourse is meaningful. There is a significant positive and positive effect between behavioral factors and scientific discourse $(\mathrm{r}=0.756)$, based on the determination coefficient $\left(\mathrm{r}^{2}\right) 30.9 \%$ of the variance between behavioral factors and common scientific discourse. Therefore, the fourth sub hypothesis that there is a meaningful effect between behavioral factors and scientific discourse is confirmed.

Table 14: Significance of step-by-step regression model in fourth sub hypothesis

\begin{tabular}{|c|c|c|c|c|c|c|}
\hline Model & \multicolumn{2}{|c|}{ Predictive variable } & $\begin{array}{c}\text { Sum of } \\
\text { squares }\end{array}$ & $\begin{array}{c}\text { Average of } \\
\text { squares }\end{array}$ & F statistics & $\begin{array}{c}\text { p-value } \\
\text { (significance) }\end{array}$ \\
\hline \multirow{2}{*}{1} & \multirow{2}{*}{$\begin{array}{c}\text { behavioral } \\
\text { factors }\end{array}$} & Regression & $20 / 217$ & $2 / 217$ & $80 / 40$ & $0 / 000$ \\
\cline { 3 - 6 } & & remainder & $61 / 347$ & $0 / 251$ & & \\
\cline { 2 - 7 } & Total & $81 / 564$ & & & \\
\hline
\end{tabular}

According to the results obtained from Table (14) and the meaningful value of P-value obtained in two phases of zero and between the factors of behavioral factors, it has been possible to predict the scientific discourse, the result is the relation between the aspect of behavioral factors and the scientific discourse, There is a significant relationship between regression model and behavioral factors that can predict scientific discourse.

Table 15: A summary of the stepwise regression model of the fourth sub-hypothesis

\begin{tabular}{|c|c|c|c|c|c|c|c|}
\hline \multirow[t]{2}{*}{ Model } & \multirow{2}{*}{$\begin{array}{l}\text { Predictive } \\
\text { variable }\end{array}$} & \multirow{2}{*}{$\begin{array}{c}\text { Coefficient } \\
\text { Scale }\end{array}$} & \multirow{2}{*}{$\begin{array}{l}\text { Coefficient } \\
\text { scrolling } \\
\text { square }\end{array}$} & \multicolumn{4}{|c|}{ Statistics } \\
\hline & & & & $\begin{array}{c}\text { Changes } \\
\text { F }\end{array}$ & $\begin{array}{c}\text { Degrees } \\
\text { of } \\
\text { freedom } \\
1\end{array}$ & $\begin{array}{l}\text { Degrees } \\
\text { of } \\
\text { freedom } \\
2\end{array}$ & $\begin{array}{c}\text { Durbin } \\
\text { Watson } \\
\text { test }\end{array}$ \\
\hline 1 & $\begin{array}{l}\text { behavioral } \\
\text { factors }\end{array}$ & $0 / 498$ & $0 / 248$ & $80 / 408$ & 1 & 245 & \\
\hline
\end{tabular}

The results from Table (15) show that behavioral factors of dimensions in the first step are $64.6 \%$ of the ability to predict scientific discourse.

Table 16: Regression coefficients of the fourth sub-hypothesis

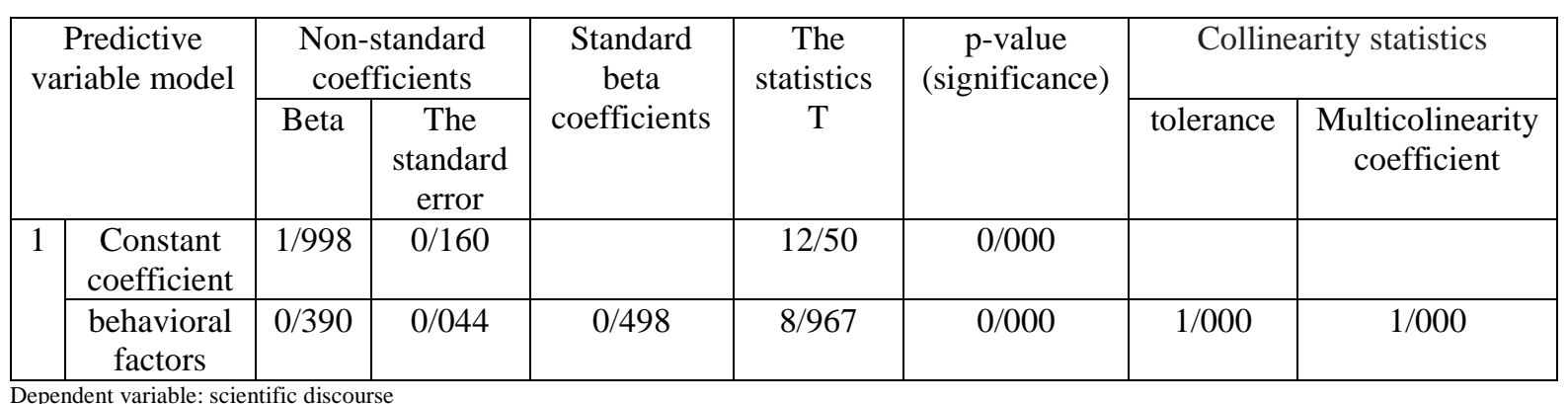


As can be seen in Table (16), stepwise regression, behavioral factors with a t-value of 50/12 and a significant level of $0 / 000$ at $95 \%$ confidence level can significantly predict the dependent variable of scientific discourse and the line equation Its regression with non-standard coefficients is as follows.

$$
\text { scientific discourse }=0 / 390 \text { behavioral factors }+1 / 998
$$

1.5 Fifth sub hypothesis: The Perceptual factors in the field of human resource development are affecting in the scientific environment.

Table 17: Correlation Coefficient between Perceptual factors and Scientific Discourses

\begin{tabular}{|c|c|c|c|}
\hline \multirow{2}{*}{ Criterion variable } & \multicolumn{3}{|c|}{ Intellectual factors of leadership } \\
\hline \multirow{2}{*}{ Predictive variables } & $\begin{array}{c}\text { Correlation } \\
\text { Coefficient }\end{array}$ & $\begin{array}{c}\text { Correlation coefficient } \\
\text { squared }\end{array}$ & $\begin{array}{c}\text { Significance level } \\
\text { (P-valeu) }\end{array}$ \\
\hline Perceptual factors & ${ }^{*} 0 / 221$ & $0 / 049$ & $0 / 028$ \\
\hline
\end{tabular}

Findings of Table (17) show that the survey coefficient between the perceptual factors and the scientific discourse is significant. There is a significant and positive effect between the perceptual factors and the scientific discourse $(r=0.221)$, based on the determination coefficient $\left(\mathrm{r}^{2}\right), 10.8 \%$ of the variance between the perceptual factors and the scientific discourse of the collaborative staff. Therefore, there is a fifth hypothesis that there is a significant effect between the perceptual factors in the field of human resource development in the field of scientific research.

Table 18: Significance of the stepwise regression model in the fifth sub hypothesis

\begin{tabular}{|c|c|c|c|c|c|c|}
\hline Model & \multicolumn{2}{|c|}{ Predictive variable } & $\begin{array}{c}\text { Sum of } \\
\text { squares }\end{array}$ & $\begin{array}{c}\text { Average of } \\
\text { squares }\end{array}$ & F statistics & $\begin{array}{c}\text { p-value } \\
\text { (significance) }\end{array}$ \\
\hline \multirow{2}{*}{1} & \multirow{2}{*}{$\begin{array}{c}\text { Perceptual } \\
\text { factors }\end{array}$} & Regression & $54 / 666$ & $18 / 222$ & $73 / 449$ & $0 / 000$ \\
\cline { 3 - 6 } & remainder & $60 / 038$ & $0 / 248$ & & \\
\cline { 2 - 7 } & Total & $114 / 703$ & & & \\
\hline
\end{tabular}

According to the results obtained from Table (18) and the meaningful value of P-value, obtained in two stages of zero, and between the component of perceptual factors, predicted the scientific discourse, it follows that there is a significant relationship between perceptual factors on scientific discourse And regression model is a meaningful model and intellectual factors can predict the scientific discourse of employees.

Table 19: Summary of regression model step by step fifth sub hypothesis

\begin{tabular}{|c|c|c|c|c|c|c|c|}
\hline \multirow[t]{2}{*}{ Model } & \multirow{2}{*}{$\begin{array}{l}\text { Predictive } \\
\text { variable }\end{array}$} & \multirow{2}{*}{$\begin{array}{c}\text { Coefficient } \\
\text { Scale }\end{array}$} & \multirow{2}{*}{$\begin{array}{l}\text { Coefficient } \\
\text { scrolling } \\
\text { square }\end{array}$} & \multicolumn{4}{|c|}{ Statistics } \\
\hline & & & & $\begin{array}{c}\text { Changes } \\
\text { F }\end{array}$ & $\begin{array}{c}\text { Degrees } \\
\text { of } \\
\text { freedom } \\
1\end{array}$ & $\begin{array}{c}\text { Degrees } \\
\text { of } \\
\text { freedom } \\
2\end{array}$ & $\begin{array}{c}\text { Durbin } \\
\text { Watson } \\
\text { test }\end{array}$ \\
\hline 1 & $\begin{array}{c}\text { Perceptual } \\
\text { factors }\end{array}$ & $0 / 690$ & $0 / 477$ & $73 / 449$ & 1 & 246 & $2 / 066$ \\
\hline
\end{tabular}

The results from Table 19 show that perceptual factors have a $69 \%$ ability to predict employees' scientific discourse. 
Table 20) Regression coefficients of the fifth sub hypothesis

\begin{tabular}{|c|c|c|c|c|c|c|c|c|}
\hline \multirow{2}{*}{\multicolumn{2}{|c|}{$\begin{array}{c}\text { Predictive } \\
\text { variable model }\end{array}$}} & \multicolumn{2}{|c|}{$\begin{array}{l}\text { Non-standard } \\
\text { coefficients }\end{array}$} & \multirow{3}{*}{$\begin{array}{l}\text { Standard } \\
\text { beta } \\
\text { coefficients }\end{array}$} & \multirow{3}{*}{$\begin{array}{c}\text { The } \\
\text { statistics } \\
\mathrm{T} \\
\\
0 / 265\end{array}$} & \multirow{3}{*}{$\begin{array}{c}\text { p-value } \\
\text { (significance) } \\
\\
0 / 000\end{array}$} & \multicolumn{2}{|c|}{ Collinearity statistics } \\
\hline & & \multirow{2}{*}{$\begin{array}{l}\text { Beta } \\
0 / 399\end{array}$} & \multirow{2}{*}{$\begin{array}{c}\text { The } \\
\text { standard } \\
\text { error } \\
0 / 229\end{array}$} & & & & tolerance & Multicolinearity \\
\hline 1 & $\begin{array}{l}\text { Constant } \\
\text { coefficient }\end{array}$ & & & & & & & \\
\hline & $\begin{array}{l}\text { Perceptual } \\
\text { factors }\end{array}$ & $0 / 107$ & $0 / 054$ & $0 / 389$ & $7 / 440$ & $0 / 000$ & $1 / 000$ & $1 / 000$ \\
\hline
\end{tabular}

As can be seen in Table (20), the perceptual factors with a t-value of $440 / 7$ and a significant level of $0 / 000$ at $95 \%$ confidence level can significantly predict the dependent variable of the employee's scientific discourse and the regression line equation with non-standard coefficients is as follows.

$$
\text { scientific discourse }=0 / 107 \text { Perceptual factors }+ \text { 0/399 }
$$

\section{Conclusion}

From the findings, one of the factors contributing to the speed of achieving the goals of the organization is the existence of efficient and creative forces and, in order for the organization to ensure its success, it is necessary to make decision making available to individuals they achieve successful results in their work in order to tolerate accountable risks, they are more likely to succeed in gaining a successful outcome, and for them maintaining or enhancing organizational status at a later stage, and this has a double impact on academic environments.

Creativity and the creation of new ideas and thoughts by academic staff in the development of scientific discourse is of particular importance and it has a high status in the university. In order to have better information for decisions about the scientific environment, there is a need for more knowledge about the intellectual capital of an organization and the development of factors in the development of human resources. Intellectual capital measurement systems must provide a thorough understanding of the capacity to create a scientific attitude in the staff, and it is even possible to quantify its information quantitatively; because employees who have a positive attitude in the organization and who strongly support their talents often have an interest in creating something that they themselves are demanding to accept, and have a strong incentive to express themselves and express more freedom in the current structure.

Academic environments should be prepared in such a way that employees can take risks and provide a new way of applying the financial and physical resources of the organization, promising a promising future, thus promoting a competitive and innovative culture. Through job factors, without regard to constraints, peripheral opportunities and, by providing innovative services and activities, provides students with the needs for academic development.

Behavioral factors or content factors include organizational factors and human relationships in the organization, which consists of behavioral factors, unofficial communication and a special interlinked pattern and the main content of the organization. These content factors are, in fact, considered to be dynamic factors of the sector and of the living entity, and any factors and variables directly related to human resources are in this direction. These behavioral factors include the performance of the university within the scope of technology, the encouragement 
of new scientific ideas, the encouragement of testing and error, the availability of resources, the appropriate reward system and the support of top managers and encouraging teamwork.

Behavioral factors in human resources provide the conditions at the university that, firstly, any person or group who wants to Career development process within the university can be implemented quickly, comfortably and effectively, and secondly, the stimulus, the facilitator and the educator Staff to perform academic and academic activities. The perceptual factors in the university are familiarity with the university's environment, the foresight and flexibility of the organization, the creation of management authority, the first step in the perceptual process at the university is that managers feel committed to academic discourse at the university. The second step is the ideas and areas where knowledge management is interested in supporting them. The university can firmly base itself on managers who are interested in training the employee and those who are eager to share their experiences with others. Since providing any logical solution for the effective communication of organizational thinking and strategies is subject to a rational approach to the Human resources management system of the organization.Therefore, with this attitude, it is suggested that the management of the organization by assigning a team of experts consisting of human resources department and management experts and experts from other parts of the organization will be responsible for designing and implementing the entrepreneurship maturity model for the employees. The following tasks can be used for the teams:

- Provide a defined operational definition of it in the organization

- Justifying managers and other members of the organization to its necessity and application in solving organizational problems

- Motivate the continuous improvement of the performance of the work and strengthen the context of its development (according to the internal conditions and organizational environment)

\section{References}

Edwards et al (2000), "Survey research action guide", Translation by Seyed Mohammad Aarabi and Davoud Izadi, Office of Cultural Research.

Aslan Khani, Mohammad Ali (1996). "Description of leadership styles and organizational climate and its relationship with knowledge management rate from the viewpoints of sports professors of selected universities of the country Doctoral dissertation, Faculty of Physical Education and Sport Sciences, University of Tehran.

Armstrong, Michael (2002), "Strategic Human Resource Management: A Practical Guide”, Translation by Seyed Mohammad Aarabi and Davoud Izadi, Office of Cultural Research.

Hosseini, abolhassan. and Hadizadeh Moghaddam, akram. and javadi, hoshmand. (2010), "Evaluating the Role of Human Resource Management in the Effectiveness of Human Resource Management", Shahid Beheshti University, Tehran.

Hosseinzade, Ali Akbar (2000). "Investigating Effective Factors on Employee Knowledge Management", Master's Thesis. Tarbiat Modares University. 
Khalil Zadeh, Noorollah (1996), "Investigating the Factors Affecting Student Satisfaction and Dissatisfaction in Payame Noor University of Urmia" , Master's Thesis. Faculty of Psychology and Educational Sciences, University of Tehran.

Dolan, sh mon, El and Schuler, Randan, (2008), "Manage women's affairs and human resources", Translators: Mohammad Ali Tusi and Saebi, Tehran: Organization Publishing Public Administration.

Sanei, Mahdi (2003), "The study of the effect of job stress and knowledge management on employees of Bank of refah in the year 2002", Master's thesis, Faculty of Management, University of Tehran.

Alavi Matin, yaghob (2015), "Identifying and Developing Appropriate Human Resources Strategies for the Bank of the Mehr eghtesad Tabriz Branches", First International Conference on Accounting, Business Management and Innovation, Gilan, Institute of Pointegrators of New Thoughts and Municipality of some sara, Farabi Cultural \& Arts Complex, Department of Culture and Guidance.

Forghani, mehrnoosh.(2011), "Relations between the field of study and organizational occupation and knowledge management among the employees of the Ministry of Economic Affairs and Finance", Master's thesis, Faculty of Management, University of Tehran.

Costa, A. , Celano, G. , Fichera, S. and Trovato, E. (2010). A new efficient encoding/decoding procedure for the design of a supply chain network with genetic algorithms. Computers \& Industrial Engineering, 59, 986-999.

Chan, F, T, S. and Chung, S, H. (2004). A heuristic methodology for order distribution in a demand driven collaborative supply chain. International Journal of Production Research, 42:1, 1-19.

Gattorna, J, L. and Jones, T. (1998). Strategic supply chain Alignment: Best Practice in supply chain management, Gower Publishing, Ltd.

Goldberg, D, E. (1989). Genetic algorithms in search, Optimization and Machine Learning, Addison-Wesley, Workingham, England.

Lambert D, M. and Cooper M, C. (1998). Supply chain management: Implementation Issues and Research opportunities. International Journal of Logistics management, 92, 1-18.

McClellan M. (2003). Collaborative manufacturing using real-time information to support the supply chain, CRC Press.

Mentzer John T. (2001). Supply chain management, Sage publications Inc.

Mendoza, A. and Ventura, J. A. (2012). "Analytical models for supplier selection and order quantity allocation. «Appl. Math. Model. Vol. 36, No, 8, 3826-3835. 